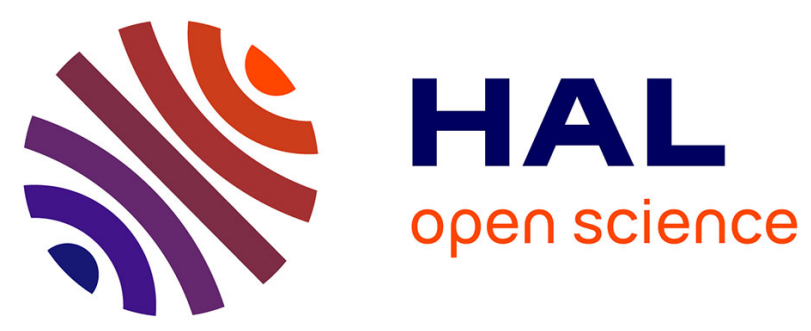

\title{
Highly porous polycaprolactone-45s5 bioglass scaffolds for bone tissue engineering
}

\author{
Paola Fabbri, Valeria Cannillo, Antonella Sola, Andrea Dorigato, Federica
}

Chiellini

\section{- To cite this version:}

Paola Fabbri, Valeria Cannillo, Antonella Sola, Andrea Dorigato, Federica Chiellini. Highly porous polycaprolactone-45s5 bioglass scaffolds for bone tissue engineering. Composites Science and Technology, 2010, 70 (13), pp.1869. 10.1016/j.compscitech.2010.05.029 . hal-00681645

\section{HAL Id: hal-00681645 \\ https://hal.science/hal-00681645}

Submitted on 22 Mar 2012

HAL is a multi-disciplinary open access archive for the deposit and dissemination of scientific research documents, whether they are published or not. The documents may come from teaching and research institutions in France or abroad, or from public or private research centers.
L'archive ouverte pluridisciplinaire HAL, est destinée au dépôt et à la diffusion de documents scientifiques de niveau recherche, publiés ou non, émanant des établissements d'enseignement et de recherche français ou étrangers, des laboratoires publics ou privés. 


\section{Accepted Manuscript}

Highly porous polycaprolactone-45s 5 bioglass ${ }^{\circledR}$ scaffolds for bone tissue engineering

Paola Fabbri, Valeria Cannillo, Antonella Sola, Andrea Dorigato, Federica Chiellini

PII: S0266-3538(10)00225-3

DOI: 10.1016/j.compscitech.2010.05.029

Reference:

CSTE 4734

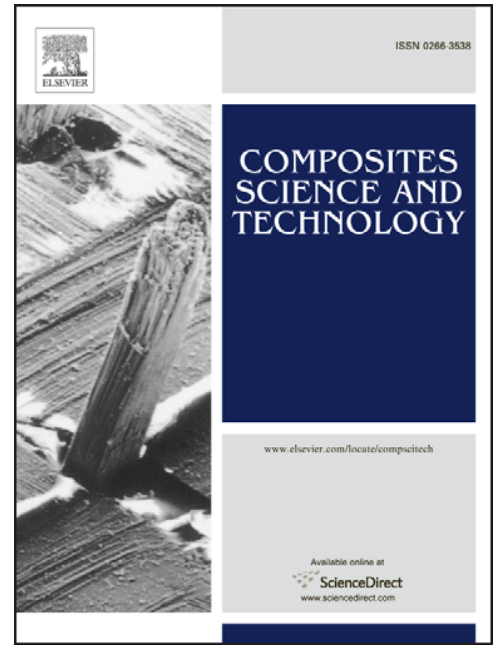

To appear in:

\section{Composites Science and Technology}

Received Date:

21 December 2009

Revised Date:

11 May 2010

Accepted Date:

30 May 2010

Please cite this article as: Fabbri, P., Cannillo, V., Sola, A., Dorigato, A., Chiellini, F., Highly porous polycaprolactone-45s5 bioglass ${ }^{\circledR}$ scaffolds for bone tissue engineering, Composites Science and Technology (2010), doi: 10.1016/j.compscitech.2010.05.029

This is a PDF file of an unedited manuscript that has been accepted for publication. As a service to our customers we are providing this early version of the manuscript. The manuscript will undergo copyediting, typesetting, and review of the resulting proof before it is published in its final form. Please note that during the production process errors may be discovered which could affect the content, and all legal disclaimers that apply to the journal pertain. 


\section{HIGHLY POROUS POLYCAPROLACTONE-45S5 BIOGLASS® SCAFFOLDS FOR BONE TISSUE ENGINEERING}

Paola Fabbri ${ }^{1,2}$, Valeria Cannillo ${ }^{1, *}$, Antonella Sola ${ }^{1}$, Andrea Dorigato ${ }^{3}$, Federica Chiellini $i^{4,5}$

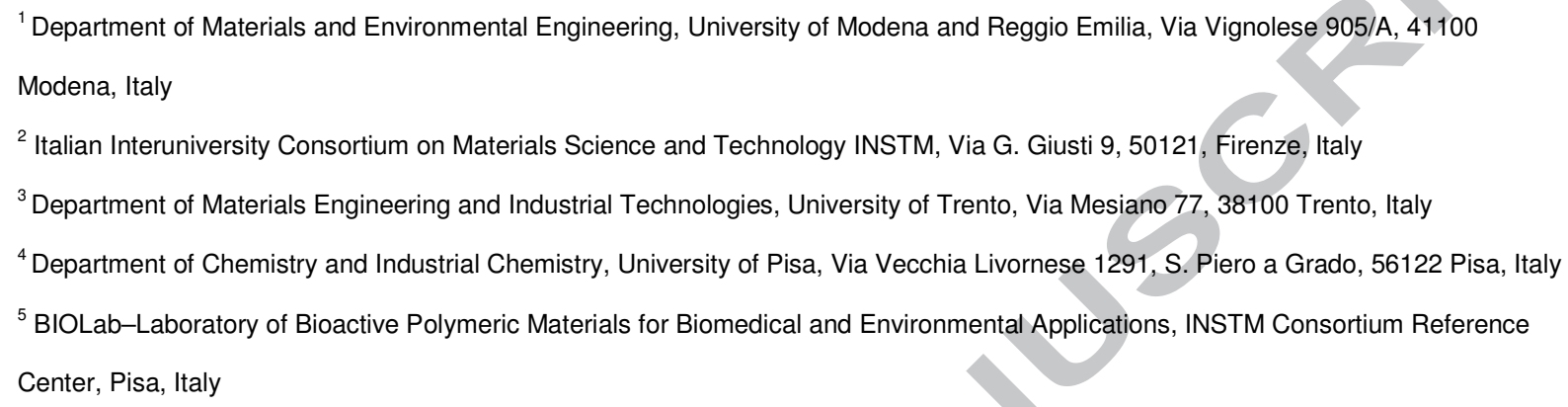

Abstract. Highly porous biocompatible composites made of polycaprolactone (PCL) and 45S5 Bioglass ${ }^{\circledR}(B G)$ were prepared by a solid-liquid phase separation method (SLPS). The composites were obtained with BG weight contents varying in the range $0-50 \%$, using either dimethylcarbonate (DMC) or dioxane (DIOX) as solvent, and ethanol as extracting medium. The porosity of the scaffolds was estimated to be about $88-92 \%$. Mechanical properties showed a dependence on the amount of BG in the composites, but also on the kind of solvent used for preparation, composites prepared with DIOX showing enhanced stress at deformation with respect to composites prepared with DMC (stress at $60 \%$ of deformation being as high as $214 \pm 17 \mathrm{kPa}$ for DIOX-prepared composites and $98 \pm 24 \mathrm{kPa}$ for DMC-prepared ones, with $50 \% \mathrm{wt} / \mathrm{wt}$ PCL of glass), as well as higher elastic modulus (whose value was $251 \pm 32 \mathrm{kPa}$ for DIOX-prepared scaffolds and $156 \pm 36$ kPa for DMC-prepared ones, always with $50 \%$ wt/wtPCL of glass). The ability of the composites to induce precipitation of hydroxyapatite was positively evaluated by means of immersion in simulated body fluid and the best results were achieved with high glass amounts (50\% wt/wtPCL). 
In-vitro tests of cytotoxicity and osteoblast proliferation showed that, even if the scaffolds are to be considered non-cytotoxic, cells suffer from the scarce wettability of the composites.

Keywords: A. Glasses; A. Polymer-matrix composites (PMCs); B. Mechanical properties; B. Porosity; Bioactivity.

\section{INTRODUCTION}

The main target of bone tissue engineering is to restore and maintain functionality to damaged or diseased bone tissues by means of a synergic combination of cell biology, materials science and engineering [1]. With this aim, in order to promote the bone regeneration, a proper scaffold can be used as a template for cell interaction and new tissue in-growth [2].

As stressed in the literature, scaffolds for bone tissue engineering must satisfy several, concurrent and often opposing requirements [2-4]. First of all, the material must be biocompatible. However, a material able to promote cell adhesion, differentiation and proliferation would be preferable. The best solution would be an osteoconductive material, which could favour a strong and stable bond with the host tissues. The material should also be bio-resorbable, with a degradation rate compatible with the re-growth rate of the natural bone. A key feature of scaffolds for bone tissue engineering is represented by their extraordinarily high porosity, which should exceed $90 \%$. This is strictly required to allow cell penetration, tissue in-growth and vascularisation, and nutrients delivery. For bone in-growth, the optimal pore size should be $75-250 \mu \mathrm{m}$. For other applications, the ideal pore size could be even larger. For example, in order to promote the in-growth of fibrocartilaginous tissue, the pore size should be in the 200-300 $\mu \mathrm{m}$ range [5], even if recent contributions question the relevance of this structural parameter for polycaprolactone scaffolds [6]. In spite of its porosity, a scaffold should possess adequate mechanical strength to be used in load bearing applications or, at least, to be easily manipulated and processed. Reliable processing 
routes should be available to obtain scaffolds able to fit the specific defects in bone tissue. And finally, the material should be suitable for commercialisation.

The main hurdle to face with is to combine bioactivity and mechanical strength, since strong materials are usually bioinert, while bioactive materials are often brittle or mechanically weak [2]. The presence of an abundant porosity further undermines the mechanical resistance of scaffolds. If the mechanical performances of many porous scaffolds (i.e. elastic modulus, compressive strength) are compared with the mean properties of cortical and cancellous bone, it is immediately evident the relatively poor mechanical integrity of the manmade scaffolds [3]. Even if it is not necessary for the scaffold to have the same mechanical properties of natural bone tissues, porous $\underline{\text { scaffolds are at least one order of magnitude weaker than cancellous bone and orders of }}$ magnitude weaker than cortical bone [7-9].

In order to overcome these limitations and to satisfy as many requirements as possible, composite scaffolds could represent an appealing solution, since composite materials benefit from the distinct properties of the constituent phases [10]. Comparing the mechanical properties of the porous composites to those of porous unfilled polymer scaffolds, the introduction of bioactive ceramic $\underline{\text { reinforcements (in most cases particles or fibers with micrometric dimensions) leads in most cases }}$ to a slight enhancement of mechanical properties. The reported increase in stiffness and strength is often below expectations, probably because of the lack of interfacial bonding strength between $\underline{\text { the ceramic phase and the polymer matrix. Many attempts were made in order to solve this }}$ problem by using surface functionalized nanofillers, showing higher specific surface area values [11-13]. The presence of a very extended interphase and of a better polymer-filler chemical compatibility can increase the interfacial bonding strength, and thus the final mechanical properties of the scaffold. However, the increase of interfacial bonding and introduction of surfactants could probably affect the degradation kinetics and the cytotoxicity of the composite. The consequences related to the introduction of functionalized nanoparticles are largely unknown and further investigations will be necessary in this field. Among all the appropriate combinations of morphology, processability and bioactivity, polymerbioglass composite scaffolds enjoy the mechanical reliability of the polymer phase and the 
excellent bioactivity of the glassy phase [14]. Currently, scaffolds are produced with natural and synthetic polymers, including polysaccharides, poly(a-hydroxyester)s, hydrogels or thermoplastic elastomers. Synthetic polymers seem to be more promising, since the synthesis process can be strictly controlled, which offers the opportunity to govern and tailor the final microstructure. In the present research, poly( $\varepsilon$-caprolactone) $(\mathrm{PCL})$ was considered because it has FDA approval in several biomedical devices, it is easily available and, most of all, it is slowly degradable, thus balancing the very high resorption rate of the bioglass $[15,16]$. The viability of PCL to obtain bioactive composites has been proven by recent publications, focused on the production and application of PCL-based composite materials loaded with various inorganic phases, such as phosphate glasses [17, 18], iron-phosphate glasses [19], glass nanofibers [20], mesoporous glasses [21], hydroxyapatite [22-28], silica [29], calcium silicate powder and Bioglass 45S5 flakes [30], tri-calcium phosphate [31-33], calcium carbonate [34], wollastonite [35]. Moreover Choong et al. coated a biodegradable PCL scaffold, made via fused deposition modelling, with a layer of calcium phosphate in order to promote cell attachment, proliferation and differentiation [36]. As regards the glass phase, the $45 \mathrm{~S} 5$ Bioglass $\AA$ (hereafter: BG) formulation was chosen. Generally speaking, bioactive glasses and ceramics are able to promote a strong mechanical bond to bone. Moreover, if their formulation is properly designed, bioglasses can positively interact also with soft tissues. This behaviour was first observed in a family of glasses belonging to the $\mathrm{SiO}_{2}-\mathrm{Na}_{2} \mathrm{O}-\mathrm{CaO}-$ $\mathrm{P}_{2} \mathrm{O}_{5}$ system, investigated by Hench and co-workers since 1970s [37]. The glass termed 45S5 Bioglass $\AA$ is the best-known and widely investigated glass of this group, due to its extreme bioactivity. Nowadays it is commercially available and used in clinical applications, such as orthopaedic, dental, maxillofacial and otolaryngological surgical implants [38]. Nevertheless, the diffusion of BG in medical devices is severely compromised by its intrinsic brittleness, which limits the application of BG to non-load bearing situations. For this reason, BG is often applied as a coating on metal or plastic substrates [39], used as a ceramic scaffold (often coated with a biodegradable polymer [40, 41], for example via impregnation methods [42]), or introduced in polymer-based composites [3, 43]. 
In this work, the approach of introducing BG into a polymer composite was chosen, and among the possible fabrication methods for highly porous polymer scaffolds [44], a solid-liquid phase separation method (SLPS) was followed [45], a well established technique, for example, for poly(lactic acid) (PLA) and poly(L-lactic acid) (PLLA) scaffolds [46-48]. Phase separation was achieved by inducing the crystallization of the solvent used to dissolve PCL, namely dimethylcarbonate (DMC) or dioxane (DIOX), followed by its chemical removal by solvent exchange using liquid ethanol. After the extraction of the frozen solvent, pores remained in place of the solvent crystals, and a highly interconnected porous material was formed. This technique can be used to fabricate scaffolds from many types of polymers and polymeric composite materials [49, 50].

PCL-BG composites were prepared with various BG weight contents and using either DMC or DIOX as solvent. The obtained samples were thoroughly characterised from a microstructural, mechanical and biological point of view in order to define the effect of the glass content and solvent nature. In fact, the main goal of the present contribution is to offer a systematic analysis of $\underline{\text { the effect of three basic parameters on the microstructure, mechanical properties and biological }}$ behaviour of the composite scaffolds, namely (i) the nature of the solvent used in the SLPS process; (ii) the amount of PCL dissolved in the initial solvent (DIOX or DMC)/polymer solution; (iii) the percentage of BG particles introduced in the composite scaffold. This outline is particularly relevant, since, as previously mentioned, the SLPS technique is mainly applied to other polymers, such as PLA and PLLA.

\section{MATERIALS AND METHODS}

\subsection{Materials}

Solvents dimethylcarbonate (DMC), ethanol 99.8\% (EtOH), methanol (MeOH), dioxane (DIOX) and tetrahydrofuran (THF) were purchased from Sigma Aldrich (Milan, Italy) and used as received without further purification. Polycaprolactone (PCL) diol of $M W=65000 \mathrm{~g} / \mathrm{mol}$ was purchased from 
Sigma Aldrich (Milan, Italy) and purified via dissolution in THF and reprecipitation in cold $\mathrm{MeOH}$, in order to eliminate residual polymerization catalysts.

The glass was produced by mixing analytical-grade $\mathrm{SiO}_{2}, \mathrm{Na}_{3} \mathrm{PO}_{4} \cdot 12 \mathrm{H}_{2} \mathrm{O}, \mathrm{Na}_{2} \mathrm{CO}_{3}$ and $\mathrm{CaCO}_{3}$ purchased from Carlo Erba Reagenti (Milan, Italy) in proper amounts [51]. The mixture was melted in a platinum crucible following the thermal cycle: i) from room temperature to $1100^{\circ} \mathrm{C}$ in 2 hours; ii) isothermal step at $1100^{\circ} \mathrm{C}$ for 1 hour; iii) from $1100^{\circ} \mathrm{C}$ to $1450^{\circ} \mathrm{C}$ in 40 minutes; iv) isothermal step at $1450^{\circ} \mathrm{C}$ for 30 minutes. The melted glass was cast into room-temperature water to obtain a frit, which was dry-milled in a porcelain jar using $\mathrm{Al}_{2} \mathrm{O}_{3}$ spheres and then sieved below $45 \mu \mathrm{m}$.

\subsection{Solid-liquid phase separation (SLPS)}

PCL solutions were prepared by dissolving the polymer at concentrations $2,3.5$ or $5 \% \mathrm{wt} / \mathrm{vol}$ in either DMC or DIOX. BG was added in amounts $25 \%$ or $50 \%$ by weight with respect to PCL. Homogeneous mixtures were obtained by means of vigorous mechanical stirring of the solutions, followed by 15 minutes of sonication. After mixing, solutions were placed inside disposable aluminum dishes of $60 \mathrm{~mm}$ diameter, and cooled at $-18^{\circ} \mathrm{C}$. After 18 hours, the frozen samples were extracted from the holders and fully immersed in $\mathrm{EtOH}$ bath pre-cooled at $-18^{\circ} \mathrm{C}$, where they were kept for 48 hours, with solvent refresh every 3 hours. At the end of the extraction procedure, the porous PCL-BG composites were taken out the freezer and completely dried under vacuum.

\subsection{Morphological characterization of PCL-BG scaffolds}

Morphology of the scaffolds was investigated by scanning electron microscopy (SEM) using a XL30 instrument (Philips) over gold-coated samples; both surface and cross section were analysed. The overall porosity was evaluated with a dual-chamber mercury porosimeter (Micromeritcs Autopore II 9512), using a pressure up to 1.7 atm in the first chamber and up to 400 atm in the second one.

\subsection{Mechanical characterization of PCL-BG scaffolds}

Quasi-static compression tests were performed on $20 \times 20 \times 6 \mathrm{~mm}^{3}$ specimens by using an Instron 4502 (Instron, MA, USA) electromechanical tensile testing machine, equipped with a $10 \mathrm{kN}$ load cell. According to UNI EN ISO 604 standard, the measurements were performed at ambient temperature $\left(25^{\circ} \mathrm{C}\right)$ at a compression rate of $1 \mathrm{~mm} / \mathrm{min}$. At least five specimens were tested for 
each sample. Following ISO 527 standard, a secant modulus (E) was evaluated between strains of

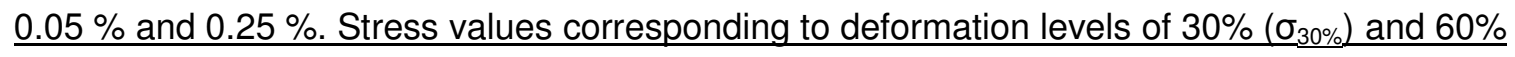
$\underline{\left(\sigma_{60 \%}\right) \text { were also determined. }}$

\subsection{Mineralization assays}

Acellular simulated body fluid (containing $\mathrm{NaCl}, \mathrm{NaHCO}_{3}, \mathrm{KCl}, \mathrm{MgCl}_{2}, \mathrm{HCl}, \mathrm{CaCl}_{2}, \mathrm{Na}_{2} \mathrm{SO}_{4}$, $\mathrm{Na}_{2} \mathrm{HPO}_{4}$ and $\left(\mathrm{CH}_{2} \mathrm{OH}\right)_{3}(\mathrm{CNH})_{2}$ as buffering agent) was prepared by following the Kokubo procedure and recipe [52]. PCL-BG composite samples (3 specimens, $1 \times 1 \mathrm{~cm}^{2}$, for every composite) were immersed in SBF at $37^{\circ} \mathrm{C}$ and kept in vertical position for 1,2 and 4 weeks. After the period of immersion, formation of hydroxyapatite $(\mathrm{HA})$ on the sample's surface was evaluated by SEM using an Environmental Scanning Electron Microscope (ESEM, Quanta-200 FEI Company) operated in low-vacuum mode (0.5 Torr) and coupled with an X-ray Energy Dispersion Spectrometer (X-EDS, Oxford INCA-350), and X-ray diffraction (XRD), using a X'Pert PRO diffractometer (PANalytical) operated in the $20^{\circ}-70^{\circ} 2 \theta$ range with step-size of $0.017^{\circ}$ and steptime of $91.2 \mathrm{~s}$.

\subsection{Cells culture and proliferation assays}

\subsubsection{Materials}

Cell line MC-3T3-E1 (CRL 2594) was obtained from American Type Culture Collection (ATCC) and propagated as indicated by the supplier. Dulbecco's Modified Eagles Medium (DMEM), $0.01 \mathrm{M} \mathrm{pH}$ 7.4 phosphate buffer saline without $\mathrm{Ca}^{2+}$ and $\mathrm{Mg}^{2+}(\mathrm{PBS})$, Fetal Bovine Serum (FBS), Calf Serum (CS), trypsine/EDTA, glutamine, and antibiotics (penicillin/streptomycin) were purchased from GIBCO Brl. Cell proliferation reagent WST-1 was purchased from Roche Diagnostic.

PhalloidinAlexa488® and 4',6-diamidino-2-phenylindole (DAPI) were purchased from Invitrogen (NewYork, NY, USA). Cell Proliferation Assay WST-1 was purchased from Roche Diagnostic. Tissue culture grade disposable plastics were obtained from Corning Costar.

\subsubsection{Cell adhesion and proliferation onto PCL-BG scaffold}

To investigate the ability of the prepared PCL-BG scaffolds to support cell adhesion and proliferation, a scaffold sample was cut into $100 \mathrm{~mm}$ diameter disc and placed into a Cell Crown24 sample holder (Scaffdex, Finland) in 24 well culture plates. MC3T3-E1 mouse preosteoblast cells 
were seeded onto the scaffold at a concentration of $1 \times 10^{4}$ and allowed to proliferate for 5 days at $37^{\circ} \mathrm{C}$ in a $5 \% \mathrm{CO}_{2}$ enriched atmosphere. DMEM supplemented with $10 \% \mathrm{FBS}, 2 \mathrm{mM}$ L-glutamine, $1 \mathrm{mM}$ sodium pyruvate and $100 \mathrm{U} / \mathrm{ml}: 100 \mathrm{lg} / \mathrm{ml}$ penicillin:streptomycin was used as complete culture media and renewed every $48 \mathrm{~h}$. At the end of the incubation time samples were analyzed for cell proliferation by means of WST-1 tetrazolium salts.

Cell morphology was investigated by means of confocal laser scanning microscopy (CLSM) and SEM. For CLSM analysis cells grown onto PCL-BG films were fixed with $3.8 \%$ paraformaldehyde in PBS 0.01M pH 7.4, permeabilized with a PBS $0.01 \mathrm{M} /$ Triton X-100 solution (0.2.\%) for 5 min and incubated with a PBS $0.01 \mathrm{M}$ solution of DAPI and phalloidin-Alexa488® for $45 \mathrm{~min}$ at room temperature. After dyeing incubation samples were washed with PBS before mounting on a glass slide and sealing with resin for microscopic observation.

A Nikon Eclipse TE2000 inverted microscope equipped with a EZ-C1 confocal laser (Nikon, Japan) and Differential Interference Contrast (DIC) apparatus and a 609 oil-immersion objective were used to analyze the samples. A $405 \mathrm{~nm}$ laser diode (405 nm emission) and Argon ion laser (488 $\mathrm{nm}$ emission) were used to excite, respectively, DAPI and FITC fluorophores. Images were captured with Nikon EZ-C1 software with identical settings for each sample. Images were further processed with GIMP (GNU Free Software Foundation) Image Manipulation Software and merged with Nikon ACT-2U Software.

For SEM analysis samples were fixed with solution of $2.5 \%$ glutaraldehyde in PBS1 $0.01 \mathrm{M}$ for $1 \mathrm{~h}$ at room temperature and dehydrated by the use of a series of ethanol solutions $(25,50,70$ and $100 \% \mathrm{v} / \mathrm{v})$. Afterward constructs were air dried overnight at room temperature and sputter coated with gold and analyzed under a JEOL LSM5600LV scanning electron microscope.

\section{RESULTS}

\subsection{Highly porous PCL-BG composites by solid-liquid phase separation method (SLPS)}

Among the fabrication technologies available to produce composite scaffolds from bioactive glasses and polymeric materials, the solid-liquid phase separation method (SLPS) can produce 
homogeneous and highly porous structures by means of a simple experimental procedure. The phase separation is induced by lowering the temperature under the freeze point of the solvent used to dissolve the polymer and disperse the bioactive glass, in order to solidify the composite into its interstitial spaces. The frozen solvent is then chemically extracted by contact with another solvent (liquid-solid separation), miscible with the former and having lower freeze point; the extracting solvent progressively removes the ice solvent and pores and cavities remain in place of it. Main advantages connected with SLPS are related to the extremely high levels of porosity that can be obtained (>95\%), and full control on the final composite composition. In the case of the present study, SLPS resulted particularly convenient to prepare composites of 45S5 Bioglass ${ }^{\circledR}$ with PCL, an aliphatic polyester of well known biodegradability and mechanical properties. The effect of the following parameters on the final morphology of the PCL-BG composites was evaluated:

- kind of solvent used to dissolve PCL and disperse BG (dimethylcarbonate (DMC) or dioxane $(\mathrm{DIOX})$;

- concentration of PCL in the solution (2, 3.5 or $5 \% \mathrm{wt} / \mathrm{vol})$;

- amount of BG in the composite ( $25 \%$ or $50 \%)$.

SEM pictures reported in Table 1 compare the morphologies obtained with either DMC or DIOX, at different PCL concentrations (BG content kept constant at 25\%). Chemical extraction of the frozen solvent was always performed by using EtOH. SEM pictures of the respective cross-sections are reported in Table 2.

Larger pores and more homogeneous pore distributions were obtained by using DIOX as solvent rather than $\mathrm{DMC}$, but negligible differences in the composite morphologies were noted by varying the PCL concentration in the range between 2 and $5 \% \mathrm{wt} / \mathrm{vol}$. In both cases the oriented tubular pores described in the literature for analogous polymer-BG composites (namely PDLLA-BG) obtained by thermally induced phase separation (TIPS, frozen solvent extraction performed under vacuum) were noted [14]. In preliminary studies, our composites based on PCL gave less porous morphologies when prepared by TIPS with respect to SLPS under analogous experimental conditions, so further investigations were performed just on samples prepared by SLPS. A possible 
reason for that can be found in the higher extraction power of EtOH in SLPS with respect to the vacuum applied by our equipment, which was probably not strong enough to perform a fast and complete sublimation of DIOX. Figure 1 shows an example of the morphology of PCL-BG composites containing 25\%wt BG, prepared by SLPS in DIOX, PCL concentration at 5\% wt/vol. The effect of $B G$ content $(0,25,50 \%$ wt/wt with respect to $P C L)$ on the final morphology of the composite was also evaluated, as can be seen by SEM images reported in Figure 2 for composites prepared by SLPS with DIOX at $5 \%$ wt/vol. A strong influence of the BG content was noted for the highest amount of BG, namely $50 \%$, which resulted in a rougher and differently porous morphology. Only relatively high contents of BG (not lower than $25 \%$ ) were considered since PCL is biocompatible, but not bioactive and it is substantially hydrophobic, so high percentages of BG are required to confer bioactivity to the PCL-BG composite; on the other hand, preliminary tests (data not reported) suggested that contents of BG exceeding $50 \mathrm{wt} \%$ were likely to cause an uneven distribution of the glass particles. Complementary to what observed by SEM, values of porosity are reported in Table 3 for PCL-BG composites prepared in DMC or DIOX and BG amounts varying between 0 and $50 \%$ with respect to PCL. Table 3 reports porosity data only for composites prepared at $5 \% \mathrm{wt} / \mathrm{vol}$ of PCL concentration, due to the fact that morphologies observed by SEM for different polymer concentrations did not show significant differences. Values are reliable within the instrument accuracy (about $6 \%$, but they should be considered mainly for comparative purposes, due to the deformability of polymer scaffolds. It is noteworthy that, in spite of the different morphology observed by SEM for PCL-BG composites containing $25 \%$ or $50 \%$ of BG, and prepared in DIOX at $5 \% \mathrm{wt} / \mathrm{vol}$ polymer concentration (see Figure $2 \mathrm{~b}$ and $2 \mathrm{c}$ ), values of porosity are comparable (approximately 90\%). Numerical values deduced from porosimeter tests indicate that the average pore diameter is in the $10-40 \mu \mathrm{m}$ range for all the PCL-BG composites, however the SEM images clearly prove the development of an interconnected network of much larger pores, up to some hundreds of micrometers, the average value being lower due to the presence of a very rich and $\underline{\text { diffused microporosity. }}$ 


\subsection{Mechanical properties}

$\underline{\text { Quasi-static compressive tests were carried out on PCL-BG porous composites containing }}$ different amounts of BG and obtained by SLPS, using either DMC or DIOX as solvent. Typical compressive stress-strain curves are shown in Figures $3 \mathrm{a}$ and $3 \mathrm{~b}$ for composites prepared using $\underline{D M C}$ and DIOX as solvent, respectively, while numerical values of the elastic modulus, of the stress at $30 \%$ and $60 \%$ of deformation are reported in Table 4 . Interestingly, a notable influence of the solvent used to prepare the composites was found, the ones prepared with DIOX showing a markedly higher elastic modulus and compression resistance with respect to the ones prepared with DMC. This results from the different morphologies that characterize the two sets of composites, as reported in Tables 1 and 2, because the more regular alveolar structure typical of DIOX-samples induces higher stiffness and compressive resistance in the material. As expected, $\underline{\text { the introduction of BG microparticles causes a noticeable increase of the materials stiffness with }}$ $\underline{\text { the filler amount. If stress values at different deformation levels are considered, it can be }}$ concluded that the reinforcing action provided by BG particles is more evident at higher deformations, when the influence of the porosity on the mechanical behaviour plays a minor role and the compressive properties of the bulk polymer become relevant. Furthermore, the enhancement of $\sigma_{30 \%}$ and $\sigma_{60 \%}$ in composites prepared with DIOX is more relevant than that experienced in composites prepared with DMC, probably because of the different pore structure.

\subsection{Mineralization tests in SBF}

Assessment of bioactivity was carried out on PCL-BG porous composites by immersion in SBF for different times, followed by XRD investigation to reveal crystallization of hydroxyapatite onto the composite surface. Table 5 reports a summary of the characteristics of different PCL-BG composites, prepared using a polymer concentration equal to $5 \% \mathrm{wt} / \mathrm{vol}$, after immersion in SBF. $\underline{\text { In}}$ the same Table 5, representative ESEM images (pressure: 0.5 Torr) are included. Moreover Figure 4 reports a SEM picture of the PCL-BG composite containing $50 \mathrm{wt} \%$ of BG, prepared in DIOX at a polymer concentration equal to $5 \% \mathrm{wt} / \mathrm{vol}$, where apatite precipitates on the composite surface can be easily identified after 4 weeks of immersion in SBF. 
The evaluation of the mineralization tests suggests that the introduction of BG particles exerts a prominent role in the development of apatite in SBF, since only the samples containing $50 \mathrm{wt} \%$ of BG developed a stable layer of apatite after immersion in SBF for 4 weeks. It is likely that the scarce wettability of PCL may have retarded the SBF interaction with the glass particles, making $\underline{\text { the development of apatite uncertain in short periods of immersion. However, high contents of }}$ glass (namely $50 \mathrm{wt} \%$ ) and long permanence times in SBF may have favoured the contact and reaction of the BG particles with the SBF, inducing the mineralization of apatite. Figure 5 shows an example of the apatite nuclei that are generating on the surface of the BG particles (micrographs taken on the sample obtained using DMC as solvent and containing 50\% BG; immersion time: 4 $\underline{\text { weeks). }}$

\subsection{Cells adhesion and proliferation tests}

In the view of a potential application for bone tissue engineering, a preliminary biological evaluation of the prepared PCL-BG composite scaffolds to sustain cell adhesion and proliferation was carried out by using the mouse calvaria-derived pre-osteoblastic cell line MC-3T3-E1. Quantitative evaluation of cell proliferation onto the composites containing different amounts of BG (25 or 50 $\mathrm{wt} / \mathrm{wt} \mathrm{PCL}_{\mathrm{L}}$ ), prepared in either DIOX or DMC, was carried out after 5 days of static culture and evaluated by means of WST-1 tetrazolium salt. It is noteworthy that cell seeding procedure resulted particularly difficult on all samples, due to the scarce wettability of the PCL matrix despite the very high porosity of the scaffolds.

Results highlighted a cell proliferation onto all the investigated samples of approximately $25 \%$ with respect to the cells grown onto tissue culture polystyrene, used as control standard. No appreciable effect was found by varying BG content or solvent used for preparation. It was noted that the proliferative capacity of the cells was hampered by the hydrophobicity of the composite samples. As shown by confocal microscopy images in Figures $6 \mathrm{a}$ and $6 \mathrm{~b}$, cells grown onto composites prepared in DIOX and DMC respectively presented a poorly expanded cytoplasm (green colour) with nuclei (blue colour) that lost their globular shape. 


\section{DISCUSSION.}

With respect to other experimental techniques conventionally used to produce polymer-bioglass highly porous composites for bone tissue engineering, the approach applied in the present study offers several advantages, mainly related to the extreme control that can be easily taken on the final composite morphology and structure. In fact, solid-liquid phase separation (SLPS) conjugates the feasibility on any appropriate polymer solution typical of thermally induced phase separation (TIPS) to the easiness of frozen solvent removal by another miscible solvent instead of vacuum sublimation. This method, due to the long-lasting contact between the frozen solvent used for the polymer solution (dimethylcarbonate, DMC, or dioxane, DIOX, in the present study) and ethanol, permits to easily obtain a highly porous structure without use of vacuum equipments and performing a complete and effective chemical solvent removal and composite's washing by ethanol [53]. This represents an advantage with respect to TIPS, especially if DIOX is used, since it is suspected to be dangerous for human health [54] and therefore it must be completely removed before implantation. In this study, SLPS applied to PCL-BG composites resulted particularly suited to prepare composites with extremely high porosity ( $>90 \%)$, but it was impossible to fine-tune the porosity by changing the concentration of the polymer solution from $2 \mathrm{wt} / \mathrm{vol} \%$ to $5 \mathrm{wt} / \mathrm{vol} \%$. In fact, porosity varied in the range $88-92 \%$ without a specific trend in function of the PCL concentration used. On the contrary, small but reproducible effect of the kind of solvent used on the porosity was found, keeping other experimental parameters constant: in all cases composites prepared in DMC resulted more porous than the correspondent ones prepared in DIOX, with higher overall porosity percent. This is a further advantage mainly in relation to the fact that DMC is also considered a better choice than DIOX for the chemical risks correlated to the latter, as previously mentioned. The SLPS fabrication method not only produced a porosity level convenient for cell proliferation (about $90 \%$ ), but also a proper pore size distribution and interconnectivity; images reported throughout the paper (Tables 1 and 2; Figure 2) clearly show macropores and macrotubules of average dimension in the range $100-300 \mu \mathrm{m}$, connected by pores of smaller dimension $(10-50$ $\mu \mathrm{m})$. This peculiar interconnected dual morphology is widely considered as ideal for cell 
proliferation because it allows optimal body fluid circulation and cell arrangement $[2,55]$. Similar morphologies can be easily obtained by techniques based on freeze-drying [56] and in some limited cases for PCL solutions even by salt-leaching [57].

The possibility to conveniently incorporate bioactive glass particles of proper chemical composition and morphology into the polymer solution prepared for SLPS was exploited to homogeneously disperse BG powders in PCL even in very high amounts (up to $50 \% \mathrm{wt} / \mathrm{wt} \mathrm{PCL}_{\mathrm{L}}$ ). The powders were optimally dispersed in the polymer solution by vigorous mechanical stirring followed by ultrasonication before freezing the solution; the fast occurrence of the solvent solidification and consequent phase separation avoids BG particle precipitation towards the bottom of the sample holder, thus ensuring that the optimal dispersion of BG throughout the PCL matrix is maintained. This represents a strong advantage with respect to other preparation techniques such as, for example, salt-leaching, because an optimal and homogeneous distribution of bioactive particles into the polymer matrix is mandatory to get high integration of the scaffold into the natural tissues. In fact PCL, along with polyhydroxyalcanoates, is the most widely diffused biodegradable and noncytotoxic polymer used as biomaterial for the production of scaffolds for tissue engineering [58], since it shows long bioresorption rates, which are appropriate for long bone tissue regeneration in orthopaedic applications [5], and suitable mechanical properties. Unfortunately it has poor interaction with biological fluids and this limits cells adhesion and proliferation. Therefore the introduction of high amounts of well dispersed bioactive particles results mandatory. In this regard, bioactive silicate glasses such as $45 S 5$ Bioglass ${ }^{\circledR}(B G)$, discovered by Hench in 1969 [37], represent one of the best inorganic components to be included in polymer-based composite scaffolds for bone tissue engineering, due to their ability to bond to both hard and soft biological tissues, being osteogenetic and osteoconductive [59]. Fully inorganic porous scaffolds produced with BG are mechanically weak and brittle, while the inclusion of BG particles inside polymer composites provides a proper solution to combine mechanical properties, biological activity and possibility to produce scaffolds of the desired shape $[1,60]$. Considering the mechanical performances of the prepared scaffolds, it emerges that the stiffness of the unfilled PCL scaffolds is slightly lower than that reported in literature for similar systems. For 
instance, Rezwan et al. indicated for porous biodegradable polymers with a porosity level higher

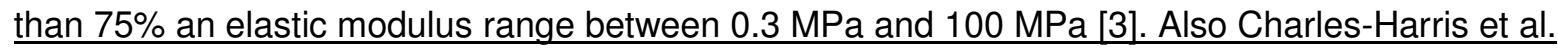
reported for PLA/calcium phosphate composites with a porosity of $95 \%$ an elastic modulus of about $300 \mathrm{kPa}$ [61]. Similar values were also found by Meretoja et al. on PCL-PDLLA scaffolds with lower porosity levels [62]. The relatively low stiffness detected for the unfilled scaffolds in this paper can be attributed to the particular pore structure and to the high porosity levels obtained with SLPS technique. The inclusion of BG particles into a polymer scaffold generally induces an increase in the elastic modulus of the polymer, which is often proportional to the filler loading [3]. Also in the present case, an interesting enhancement of the material stiffness due to the presence of BG microparticles can be detected (Figure 7a). Considering that the compressive modulus of unfilled DMC-PCL is about three times lower than that of DIOX-PCL, the relative increase due to BG addition is more relevant in the case of PCL scaffolds prepared from DMC (around $100 \%$ for a filler content of $50 \mathrm{wt} \%$ ).

As often happens with biodegradable thermoplastic foams, the prepared PCL scaffolds do not $\underline{\text { manifest a critical stress under compressive loading, but a continuous increase of the load due to }}$ the progressive porosity reduction [9]. For these reasons the compression resistance of the $\underline{\text { scaffolds was evaluated computing the stresses associated at different strain levels }\left(\sigma_{30 \%} \text { and }\right.}$ $\left.\underline{\sigma}_{60 \%}\right)$. Even if it is widely accepted that it is not essential for the scaffold to have the same $\underline{\text { mechanical strength of natural bone tissues, proper mechanical properties are requested for a }}$ correct manipulation and positioning of the scaffolds. Different values of the compressive strength are reported in literature for polymer composite scaffolds for bone tissue engineering with a porosity level higher than $75 \%$, typically ranging from $\sim 0.075$ to $\sim 4.0 \mathrm{MPa}$ [3]. Therefore, it is possible to conclude that all the PCL-BG composites presented in this study possess such appropriate features, showing also an increase of the compressive strength with increased BG loading, as reported in Figure 7b. Interestingly, the compressive strength values recorded for PCLBG highly porous (> 90\%) composites containing $50 \mathrm{wt} \%$ of BG resulted almost as high as the compressive strength reported for fully inorganic $45 S 5$ Bioglass ${ }^{\circledR}$ sponges produced by polymer- 
sponge replication technique [60], which can be considered a notable results if the better processability of polymer composites is taken into account.

According to literature references, it could be hypothesized that the relatively weak interfacial interactions between the hydrophilic inorganic filler and the relatively hydrophobic PCL in the prepared scaffolds negatively affects the reinforcing effect provided by the introduction of untreated BG microparticles. Consequently, the compressive behavior of the scaffolds would probably be improved with a proper surface functionalization of BG microparticles [3]. In that case, specific investigations about the effects of the organo-modification on the scaffolds cytotoxicity would have been required. Another possibility to increase the polymer-filler interaction could be represented by the introduction of BG particles at the nanoscale. In fact, Misra et al. [11] demonstrated that the addition of nanosized bioactive glass particles has a more significant effect on the mechanical and structural properties of a composite system in comparison with microparticles. In fact the larger specific surface area of the nanoparticles should lead to increased interface effects, contributing also to improved bioactivity, when compared to standard microparticles [12, 13]. Therefore, further investigations will be necessary in the future to precisely assess the role played by the filler dimension and by the surface interaction on the mechanical performances of the scaffolds. Finally, the preliminary biological assessment performed on the PCL-BG composites prepared in this study by immersion in SBF confirmed the well-known ability of BG to induce apatite precipitation onto the composite surface. Cell adhesion and proliferation tests highlighted a poor cell adhesion and proliferation, as a consequence of the high hydrophobic nature of the PCL matrix that does not allows for an optimal coating of cell adhesion cues (typically serum proteins) onto its surface. This phenomenon should be overcome by copolymerization of PCL with more hydrophilic hydroxyalcanoates or methods of chemical surface modification of the scaffolds.

\section{CONCLUSIONS.}

$\underline{\text { In the present contribution, PCL-BG composite scaffolds were produced via SLPS, using DMC or }}$ DIOX to dissolve the PCL. Three main parameters were considered, i.e. kind of solvent used to 
dissolve the polymer and disperse the BG particles (DMC/DIOX), concentration of PCL in the solution $(2,3.5$ or $5 \% \mathrm{wt} / \mathrm{vol})$, and amount of BG in the composite ( 25 or $50 \% \mathrm{wt} / \mathrm{wtPCL})$.

From a microstructural point of view, larger pores and more homogeneous pore distributions were achieved by using DIOX as solvent rather than DMC. The microstructure was also influenced by the BG content, since high amounts of glass particles (namely $50 \%$ ) gave place to rougher morphologies. Instead, negligible differences in the composite morphologies were noted by varying $\underline{\text { the PCL concentration. However, all the composite scaffolds exhibited a rich and interconnected }}$ porosity (total porosity varied in the $88-92$ vol\% range), with a diffused microporosity accompanied by very large pores, up to some hundreds of microns.

The DIOX-samples, which showed a more regular alveolar structure, achieved higher compressive resistance with respect to DMC-ones, being the stress at $60 \%$ of deformation as high as $214 \pm 17$ kPa for DIOX-prepared composites and $98 \pm 24 \mathrm{kPa}$ for DMC-prepared ones (with $50 \%$ glass). Also the stiffness was higher for DIOX-scaffolds than for DMC-ones, being $251 \pm 32 \mathrm{kPa}$ for DIOXprepared scaffolds and $156 \pm 36 \mathrm{kPa}$ for DMC-prepared ones (always with $50 \%$ glass). In turn, the reinforcing action of the BG particles caused an increase in the stiffness.

The in-vitro mineralization tests proved the preeminent role of BG particles in the development of apatite in SBF. In fact, only the samples containing 50\% glass resulted completely covered by a stable apatite layer after immersion in SBF for 4 weeks, independently of the solvent used to produce the scaffolds. A preliminary biological evaluation proved that the cell proliferation onto all the investigated samples was approximately $25 \%$ with respect to the cells grown onto tissue culture polystyrene, used as control standard. No appreciable effect was found by varying the BG content or solvent used for preparation. It is likely that the proliferative capacity of the cells was hampered by the hydrophobicity of the composite samples.

$\underline{\text { In conclusion, in order to combine morphological adequateness, mechanical strength and }}$ bioactivity, the most promising composite scaffolds were produced using DIOX as solvent and introducing $50 \% \mathrm{wt} / \mathrm{wt}_{\mathrm{PCL}}$ of BG particles. Instead the PCL concentration in the initial solution plays a minor role. Future developments will be focused on the bioactivity of the scaffolds, since the cell 
proliferation must be improved. Possible solutions could be a copolymerization of PCL with more hydrophilic hydroxyalcanoates or a chemical surface modification of the scaffolds.

\section{Acknowledgments}

Mr Fabio Ferrari is gratefully acknowledged for his helpful support in experimental work.

\section{REFERENCES}

[1] Chen Q, Roether JA, Boccaccini AR. Tissue engineering scaffolds from bioactive glasses and composite materials. Topics in tissue engineering, Vol. 4 Ch. 6, Ed. N. Ashammakhi, R. Reis \& F. Chiellini (2008).

[2] Karageorgiou V, Kaplan D, Review. Porosity of 3D biomaterial scaffolds and osteogenesis, Biomaterials 26 (2005) 5474-5491.

[3] Rezwan K, Chen QZ, Blaker JJ, Boccaccini AR. Biodegradable and bioactive porous polymer/inorganic composite scaffolds for bone tissue engineering, Biomaterials 27 (2006) 34133431.

[4] Sevens MM. Biomaterials for bone tissue engineering, Materials Today 11 (2008) 18-25.

[5] Cheung H-Y, Lau K-T, Lu T-P, Hui D. A critical review on polymer-based bio-engineered materials for scaffold development, Composites: Part B 38 (2007) 291-300.

[6] Mantila Roosa SM, Kemppainen JM, Moffitt EN, Krebsbach PH, Hollister SJ. The pore size of polycaprolactone scaffolds has limited influence on bone regeneration in an in vivo model, Journal of Biomedical Materials Research Part A 92 (2010) 359-368. Jones JR, Ehrenfried LM, Hench LL. Optimising bioactive glass scaffolds for bone tissue engineering, Biomaterials 27 (2006) 964-973.

[8] Kim HW, Knowles JC, Kim HE. Hydroxyapatite porous scaffold engineered with biological polymer hybrid coating for antibiotic Vancomycin release, Journal of Materials Science: Materials in Medicine $16(2005) 189-195$. 
[9] Blaker JJ, Maquet V, Jerome R, Boccaccini AR, Nazhat SN. Mechanically anisotropic PDLLA/Bioglas composite foams as scaffolds for bone tissue engineering, Acta Biomaterialia 1 (2005) 643-652.

[10] Barbero EJ. Introduction to Composite Materials Design, Taylor and Francis (1998).

[11] Misra SK, Mohn D, Brunner TJ, Stark WJ, Philip SE, Roy I, Salih V, Knowles JC, Boccaccini AR. Comparison of nanoscale and microscale bioactive glass on the properties of $\mathrm{P}(3 \mathrm{HB}) /$ Bioglass $\circledast$ composites, Biomaterials 29 (2008) 1750-1761.

[12] Kim HW, Kim HE, Knowles JC. Production and potential of bioactive glass nanofibers as a nextgeneration biomaterial, Advanced Functional Materials 16 (2006) 1529-1535.

[13] Jo JH, Lee EJ, Shin DS, Kim HE, Kim HW, Koh YH, Jang JH, In vitro/in vivo biocompatibility and mechanical properties of bioactive glass nanofiber and poly(e-caprolactone) composite materials, Journal of Biomedical Materials Research Part B: Applied Biomaterials 91 (2009) 213-220.

[14] Boccaccini AR, Notingher I, Maquet V, Jérôme R. Bioresorbable and bioactive composite materials based on polylactide foams filled with and coated by Bioglass $®$ particles for tissue engineering applications, Journal of Materials Science: Materials in Medicine 14 (2003) 443-450.

[15] Lam CXF, Hutmacher DW, Schantz J-T, Woodruff MA, Teoh SH. Evaluation of polycaprolactone scaffold degradation for 6 months in vitro and in vivo, Journal of Biomedical Materials Research Part $\underline{A 0(2009)} 906-919$.

[16] Puppi D, Chiellini F, Piras AM, Chiellini E. Polymeric materials for bone and cartilage repair, Progress in Polymer Science 35 (2010) 403-440.

[17] Ahmed I, Parson AJ, Palmer G, Knowles JC, Walker GS, Rudd CD. Weight loss, ion release and initial mechanical properties of a binary calcium phosphate glass fibre/PCL composite, Acta Biomaterialia 4 (2008) 1307-1314.

[18] Mohammadi MS, Ahmed I, Marelli B, Rudd C, Bureau MN, Nazhat SN. Modulation of polycaprolactone composite properties through incorporation of mixed phosphate glass formulations, Acta Biomaterialia, in press.

[19] Alani A, Knowles JC, Chrzanowski W, Ng Y-L, Gulabivala K. Ion release characteristics, precipitate formation and sealing ability of phosphate glass-polycaprolactone-based composite for use as a root canal obturation material, Dental Materials 25 (2009) 400-410.

[20] Lee H-H, Yu H-S, Jang J-H, Kim H-W. Bioactivity improvement of poly( $\varepsilon$-caprolactone) membrane with the addition of nanofibrous bioactive glass, Acta Biomaterialia 4 (2008) 622-629. 
[21] Li X, Shi J, Dong X, Zhang L, Zeng H, A mesoporous bioactive glass/polycaprolactone composite scaffold and its bioactivity behavior, Journal of Biomedical Materials Research Part A 84 (2008) 8491.

[22] Ciapetti G, Ambrosio L, Savarino L, Granchi D, Cenni E, Baldini N, Pagani S, Guizzardi S, Causa F, Giunti A. Osteoblast growth and function in porous poly $\varepsilon$-caprolactone matrices for bone repair: a preliminary study, Biomaterials 24 (2003) 3815-3824.

[23] Kim HW, Lee EJ, Kim HE, Salih V, Knowles JC. Effect of fluoridation of hydroxyapatite in hydroxyapatite-polycaprolactone composites on osteoblast activity, Biomaterials 26 (2005) 4395.

[24] Verma D, Katti K, Katti D. Bioactivity in in situ hydroxyapatite-polycaprolactone composites, Journal of Biomedical Materials Research Part A 78 (2006) 772-780.

[25] Thomas V, Jagani S, Johnson K, Jose MV, Dean DR, Vohra YK, Nyairo E. Electrospun bioactive nanocomposite scaffolds of polycaprolactone and nanohydroxyapatite for bone tissue engineering. Journal of Nanoscience and Nanotechnology 6 (2006) 487-493.

[26] Kim H-W. Biomedical nanocomposites of hydroxyapatite/polycaprolactone obtained by surfactant mediation, Journal of Biomedical Materials Research Part A 83 (2007) 169-177.

[27] Heo S-J, Kim S-E, Wei J, Kim DH, Hyun Y-T, Yun H-S, Kim HK, Yoon TR, Kim S-H, Park S-A, Shin JW, Shin J-W. In vitro and animal study of novel nano-hydroxyapatite/poly(e-caprolactone) composite scaffolds fabricated by layer manufacturing process. Tissue Engineering Part A 15 (2009) 977-989.

[28] Chuenjitkuntaworn B, Inrung W, Damrongsri D, Mekaapiruk K, Supaphol P, Pavasant P. Polycaprolactone/hydroxyapatite composite scaffolds: Preparation, characterization, and in vitro and in vivo biological responses of human primary bone cells, Journal of Biomedical Materials Research Part $A$, in press.

[29] Yoo JJ, Rhee SH. Evaluations of bioactivity and mechanical properties of poly(ع-caprolactone)/silica nanocomposite following heat treatment, Journal of Biomedical Materials Research Part A 68 (2004) 401-410.

[30] Chouzouri G, Xanthos M. In vitro bioactivity and degradation of polycaprolactone composites containing silicate fillers, Acta Biomaterialia 3 (2007) 745-756.

[31] Lei Y, Rai B, Ho KH, Teoh SH. In vitro degradation of novel bioactive polycaprolactone-20\% tricalcium phosphate composite scaffolds for bone engineering, Materials Science and Engineering $\underline{C 27(2007) 293-298}$ 
[32] Rai B, Oest ME, Dupont KM, Ho KH, Teoh SH, Guldberg RE. Combination of platelet-rich plasma with polycaprolactone-tricalcium phosphate scaffolds for segmental bone defect repair, Journal of Biomedical Materials Research Part A 81 (2007) 888-899.

[33] Erisken $\mathrm{C}$, Kalyon DM, Wang $\mathrm{H}$. Functionally graded electrospun polycaprolactone and $\beta$-tricalcium phosphate nanocomposites for tissue engineering applications, Biomaterials 29 (2008) 4065-4073.

[34] Fujihara K, Kotaki M, Ramakrishna S. Guided bone regeneration membrane made of polycaprolactone/calcium carbonate composite nano-fibers, Biomaterials 26 (2005) 4139-4147.

[35] Kotela I, Podporska J, Soltysiak E, Konsztowicz KJ, Blazewicz M. Polymer nanocomposites for bone tissue substitutes, Ceramics International 35 (2009) 2475-2480.

[36] Choong C, Triffitt JT, Cui ZF. Polycaprolactone scaffolds for bone tissue engineering - Effects of a Calcium Phosphate Coating Layer on Osteogenic Cells, Food and Bioproducts Processing 82 (2004) $\underline{117-125}$

[37] Hench LL. Bioceramics, Journal of the American Ceramic Society 81 (1998) 1705-1728.

[38] Shirtliff VJ, Hench LL. Bioactive materials for tissue engineering, regeneration and repair, Journal of materials science 38 (2003) 4697-4707.

[39] Bil M, Ryszkowska J, Roether JA, Bretcanu O, Boccaccini AR. Bioactivity of polyurethane-based scaffolds coated with Bioglass, Biomedical Materials 2 (2007) 93-101.

[40] Bretcanu O, Chen Q, Misra SK, Boccaccini AR, Roy I, Verne E, Brovarone CV. Biodegradable polymer coated 4555 Bioglass derived glass-ceramic scaffolds for bone tissue engineering, Glass Technology: European Journal of Glass Science and Technology, Part A 48(5) (2007) 227-235.

[41] Bretcanu O, Misra SK, Yunos DM, Boccaccini AR, Roy I, Kowalczyk T, Blonski S, Kowalewski TA. Electrospun nanofibrous biodegradable polyester coatings on Bioglass $®$-based glass-ceramics for tissue engineering, Materials Chemistry and Physics 118 (2009) 420-426.

[42] Baino F, Vernè E, Vitale-Brovarone C. Feasibility, tailoring and properties of polyurethane/bioactive glass composite scaffolds for tissue engineering, Journal of Materials Science: Materials in Medicine 20 (2009) 2189-2195.

[43] Yunos DM, Bretcanu O, Boccaccini AR. Polymer-bioceramic composites for tissue engineering scaffolds, Journal of Materials Science 43 (2008) 4433-4442.

[44] Ma PX. Scaffolds for tissue fabrication, Materials Today 7 (2004) 30-39.

[45] Chen VJ, Ma PX. Polymer Phase Separation, p. 125-138, Ch. 9, in Ma PX, Elisseeff J (Editors) Scaffolding in Tissue Engineering, CRC Press, Taylor \& Francis Group, Boca Raton, FL (2006). 
[46] Tu C, Cai Q, Yang J, Wan Y, Bei J, Wang S. The fabrication and characterization of poly(lactic acid) scaffolds for tissue engineering by improved solid-liquid phase separation, Polymers for Advanced Technologies 14 (2003) 565-573.

[47] Goh YQ, Ooi CP, Fabrication and characterization of porous poly(L-lactide) scaffolds using solidliquid phase separation, Journal of Materials Science: Materials in Medicine 19 (2008) 2445-2452.

[48] Budyanto L, Ooi CP, Goh YQ. Fabrication and Characterization of Porous Poly(L-lactide) (PLLA) Scaffolds Using Liquid-liquid Phase Separation, IFMBE Proceedings $21,4^{\text {th }}$ Kuala Lumpur International Conference on Biomedical Engineering 2008 (2008) 322-325.

[49] Zhang R, Ma PX. Poly( $\alpha$-hydroxyl acids)/hydroxyapatite porous composites for bone-tissue engineering. I. Preparation and morphology, Journal of Biomedical Materials Research 44 (1999) 446-455.

[50] Ma PX, Zhang R, Xiao G, Franceschi R. Engineering new bone tissue in vitro on highly porous poly( $\alpha$-hydroxyl acids)/hydroxyapatite composite scaffolds, Journal of Biomedical Materials Research 54 (2001) 284-293.

[51] Hench LL. Bioceramics: From Concept to Clinic, Journal of the American Ceramic Society 74 (1991) $1487-1510$.

[52] Kokubo T, Takadama H. How useful is SBF in predicting in vivo bone bioactivity?, Biomaterials 27 (2006) 2907-2915.

[53] Shugens C, Maquet V, Grandfils J, Teyessié P. Biodegradable and macroporous lactide implants for cell transplantation: 1. Preparation of macroporous lactide supports by solid-liquid phase separation Polymer 37 (1996) 1027-1038.

[54] MSDS on http://www.sigma-aldrich.com

[55] Legeros RZ, Lin S, Rohanizadeh R, Mijares D, Legeros JP. Diphasic calcium phosphate bioceramics: preparation, properties and application, Journal of Materials Science: Materials in Medicine 14 (2003) 201-209.

[56] Maquet V, Boccaccini AR, Pravata L, Notingher I, Jérome R. Porous poly( $\alpha$-hydroxyacid)/Bioglass ${ }^{\circledR}$ composite scaffolds for bone tissue engineering. I: preparation and in-vitro characterization, Biomaterials 25 (2004) 4185-4194.

[57] Fabbri P, Bondioli F, Messori M, Bartoli C, Dinucci D, Chiellini F. Porous scaffolds of polycaprolactone reinforced with in situ generated hydroxyapatite for bone tissue engineering, Journal of Materials Science: Materials in Medicine 21 (2010) 343-351. 
[58] Kweon HY, Yoo MK, Park IK, Kim TH, Lee HC, Lee H-S, Oh J-S, Akaike T, Cho C-S. A novel degradable polycaprolactone network for tissue engineering, Biomaterials 24 (2003) 801-808.

[59] Hench LL, Polak JM. Third generation biomedical materials, Science 295 (2002) 1014-1017.

[60] Chen QZ, Thompson ID, Boccaccini AR. 45 S5 Bioglass $®$-derived glass-ceramic scaffolds for bone tissue engineering, Biomaterials 27 (2006) 2414-2425.

[61] Charles-Harris M, Koch MA, Navarro M, Lacroix D, Engel E, Planell JA. A PLA/calcium phosphate degradable composite material for bone tissue engineering: an in vitro study, Journal of Materials Science: Materials Medicine 19 (2008) 1503-1513.

[62] Meretoja VV, Helminen AO, Korventausta JJ, Haapa-aho V, Seppala JV, Narhi TO. Crosslinked poly(E-caprolactone/D,L-lactide)/bioactive glass composite scaffolds for bone tissue engineering. Journal of Biomedical Materials Research 77A (2006) 261-268. 


\section{Figure Captions}

Figure 1. PCL-BG composite (25\%BG) prepared with DIOX by SLPS (SEM pictures $200 \mathrm{x}$ magnification, marker $50 \mu \mathrm{m})$.

Figure 2. PCL-BG composites prepared with DIOX by SLPS without BG (a), with BG $25 \%$ (b) and with BG $50 \%$ (c) (SEM pictures 200x magnification, marker $50 \mu \mathrm{m})$.

Figure 3. Compressive stress-strain curves for PCL-BG composites at different BG content, prepared using either DMC as solvent (a) or DIOX (b).

Figure 4. PCL-BG composite (BG content $50 \mathrm{wt} / \mathrm{wt}_{\mathrm{PCL}} \%$, prepared in DIOX) after 4 weeks soaking in SBF.

Figure 5. Development of apatite on a BG particle in the sample produced with DIOX and $50 \%$ BG, immersed in SBF for 4 weeks (ESEM pictures, (a) magnification 2000x, marker $20 \mu \mathrm{m}$; (b) $\underline{\text { magnification } 8000 x \text {, marker } 5 \mu \mathrm{m} \text {; instrument operated in low vacuum mode, pressure: } 0.5 \text { torr) }}$

Figure 6. Morphology of MC3T3- E1 grown on PCL-BG (25 wt/wt $\mathrm{wCL}_{\text {\% }}$ ) scaffold prepared in DIOX (a) and DMC (b). Scale bar: $30 \mu \mathrm{m}$ for both.

Figure 7. Elastic modulus (a) and compressive strength at deformation $60 \%, \sigma_{60 \%}$ (b) of PCL-BG composites at different BG content.

\section{Table Captions}

Table 1. PCL-BG composites surface morphologies obtained by SLPS (SEM pictures 200x

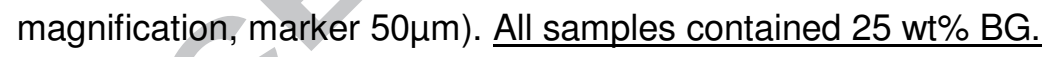

Table 2. PCL-BG composites cross-section morphologies obtained by SLPS (SEM pictures 50x magnification, marker $500 \mu \mathrm{m})$. All samples contained $25 \mathrm{wt} \%$ BG.

Table 3. Porosimetry results.

Table 4. Results of compressive strength tests.

Table 5. Observations on mineralization tests in SBF for PCL-BG composites and representative ESEM images (magnification: 500x; marker: $100 \mu \mathrm{m}$ ). 


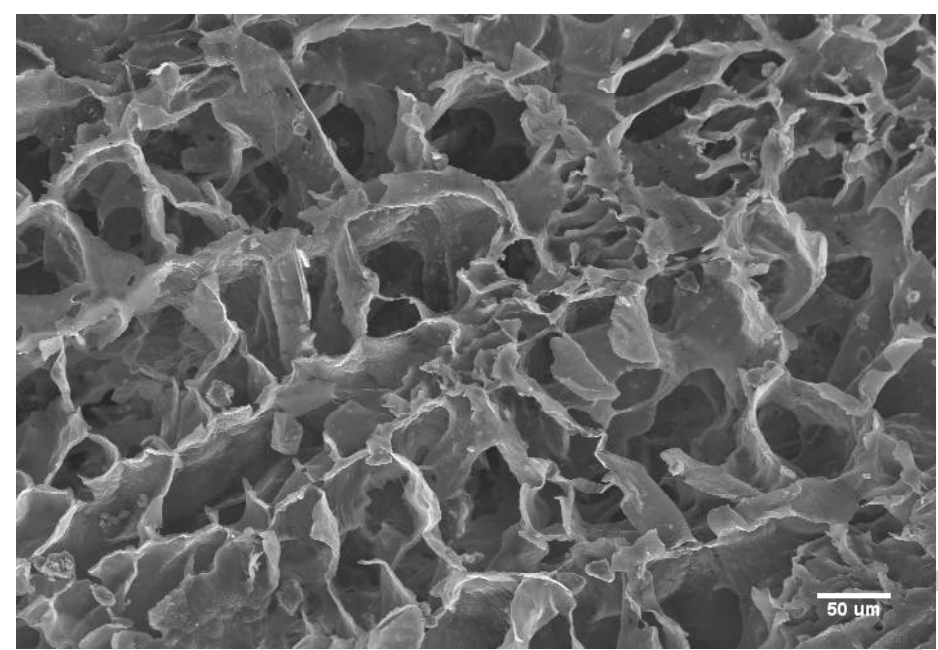

Figure 1. PCL-BG composite (25\%BG) prepared with DIOX by SLPS (SEM pictures 200x magnification,

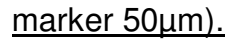


(a)

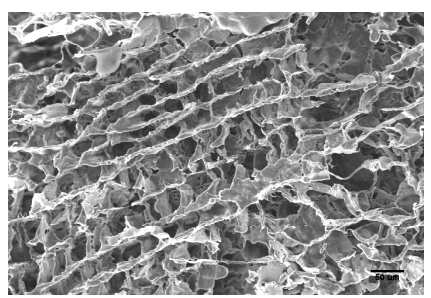

(b)
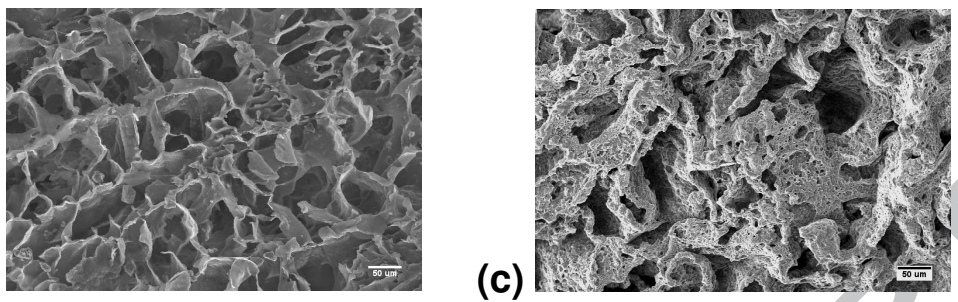

Figure 2. PCL-BG composites prepared with DIOX by SLPS without BG (a), with BG $25 \%$ (b) and with BG $50 \%$ (c) (SEM pictures 200x magnification, marker 50 $\mu \mathrm{m}$ ). 


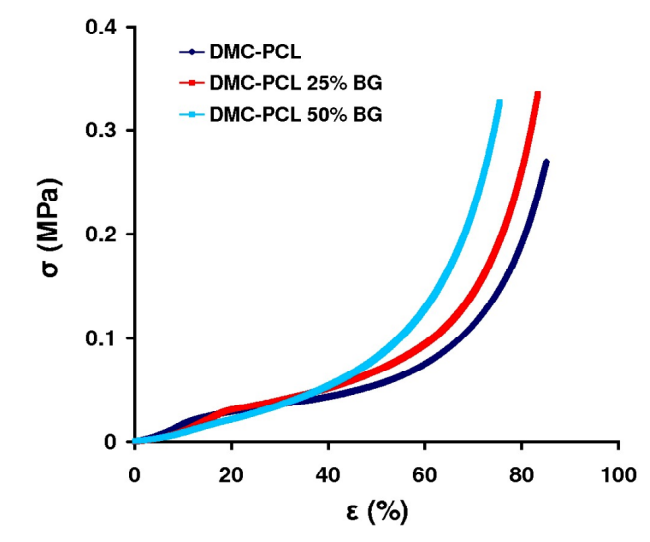

(a)

Figure 3. Compressive stress-strain curves for PCL-BG composites at different BG content, prepared using

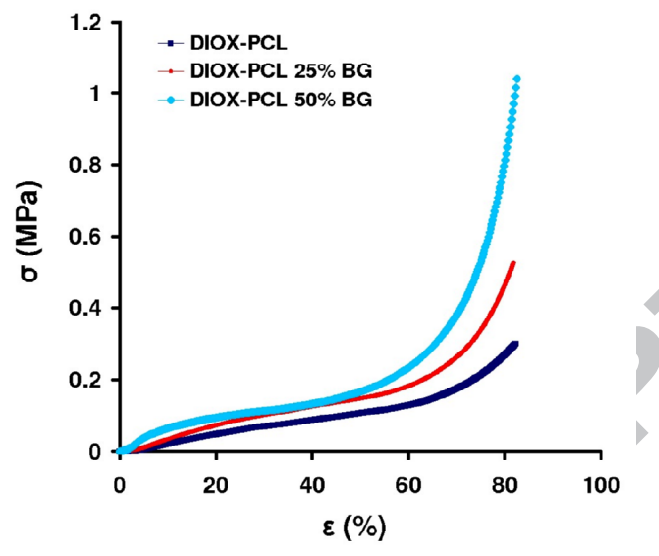

(b) content, pre

either DMC as solvent (a) or DIOX (b). 


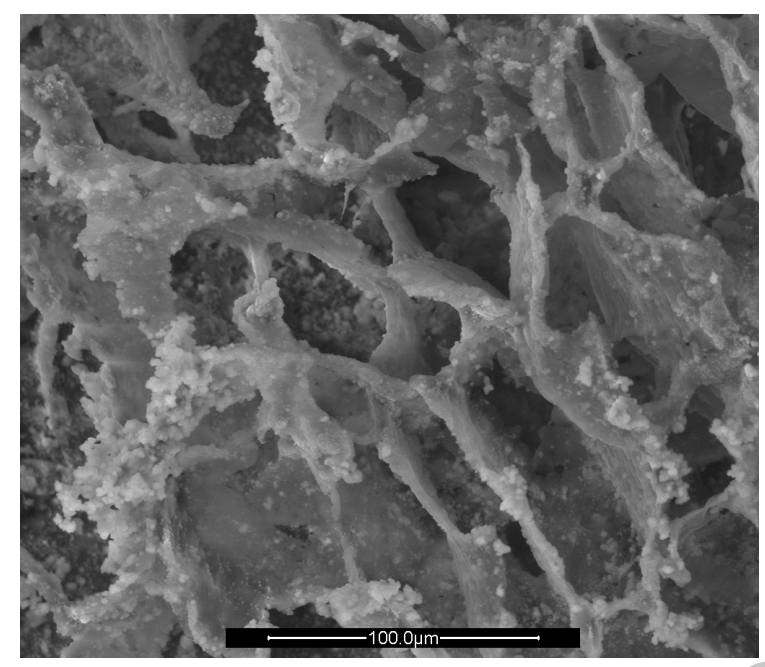

Figure 4. PCL-BG composite (BG content $50 \mathrm{wt} / \mathrm{wt}_{\mathrm{PCL}} \%$, prepared in $\mathrm{DIOX}$ ) after 4 weeks soaking in SBF. 

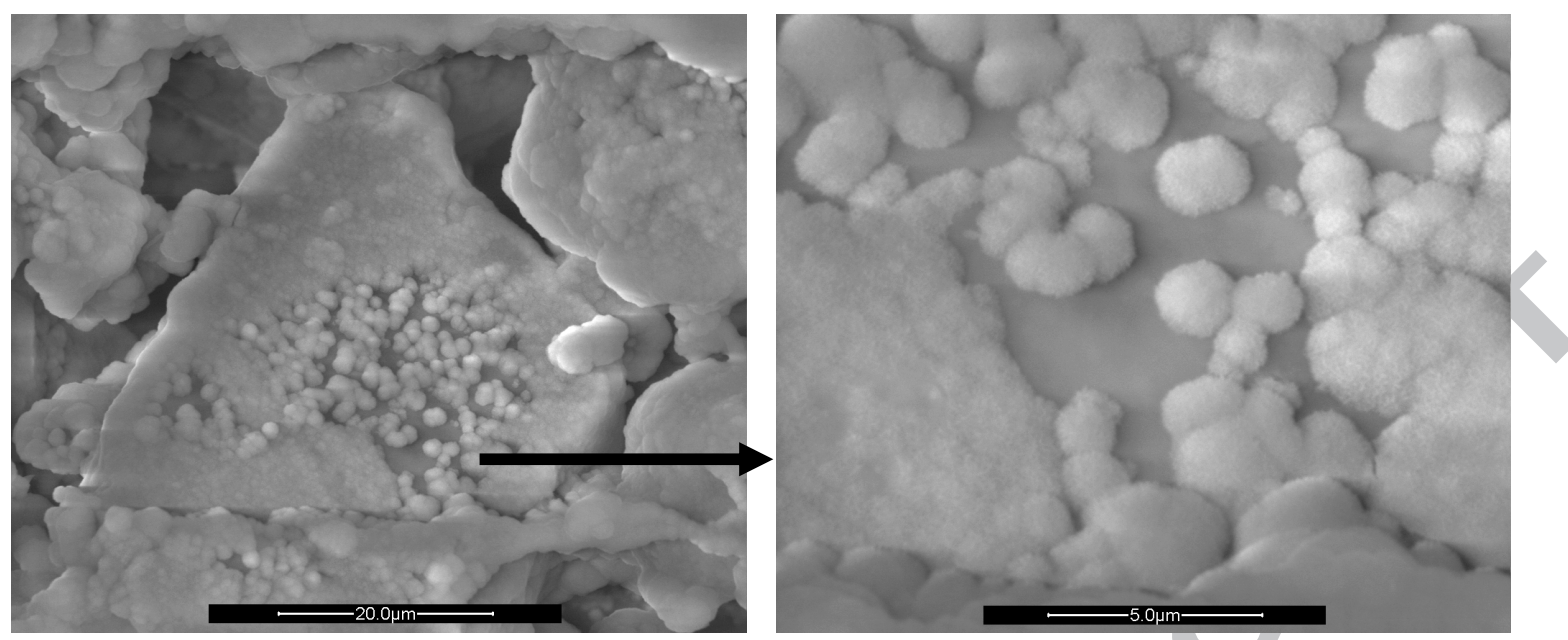

(a)

(b)

Figure 5. Development of apatite on a BG particle in the sample produced with DIOX and $50 \% \mathrm{BG}$, immersed in SBF for 4 weeks (ESEM pictures, (a) magnification 2000x, marker $20 \mu \mathrm{m}$; (b) magnification $\underline{8000 x}$, marker $5 \mu \mathrm{m}$; instrument operated in low vacuum mode, pressure: 0.5 torr) 
(a)

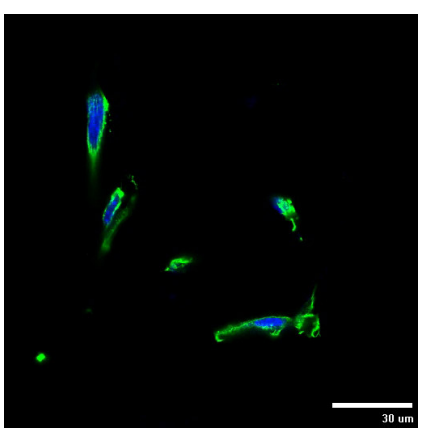

(b)

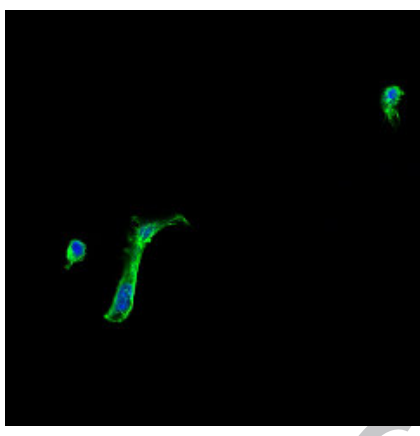

Figure 6. Morphology of MC3T3- E1 grown on PCL-BG (25 wt/wt $\mathrm{PCL}_{\mathrm{P}}$ ) scaffold prepared in DIOX (a) and DMC (b). Scale bar: $30 \mu \mathrm{m}$ for both. 

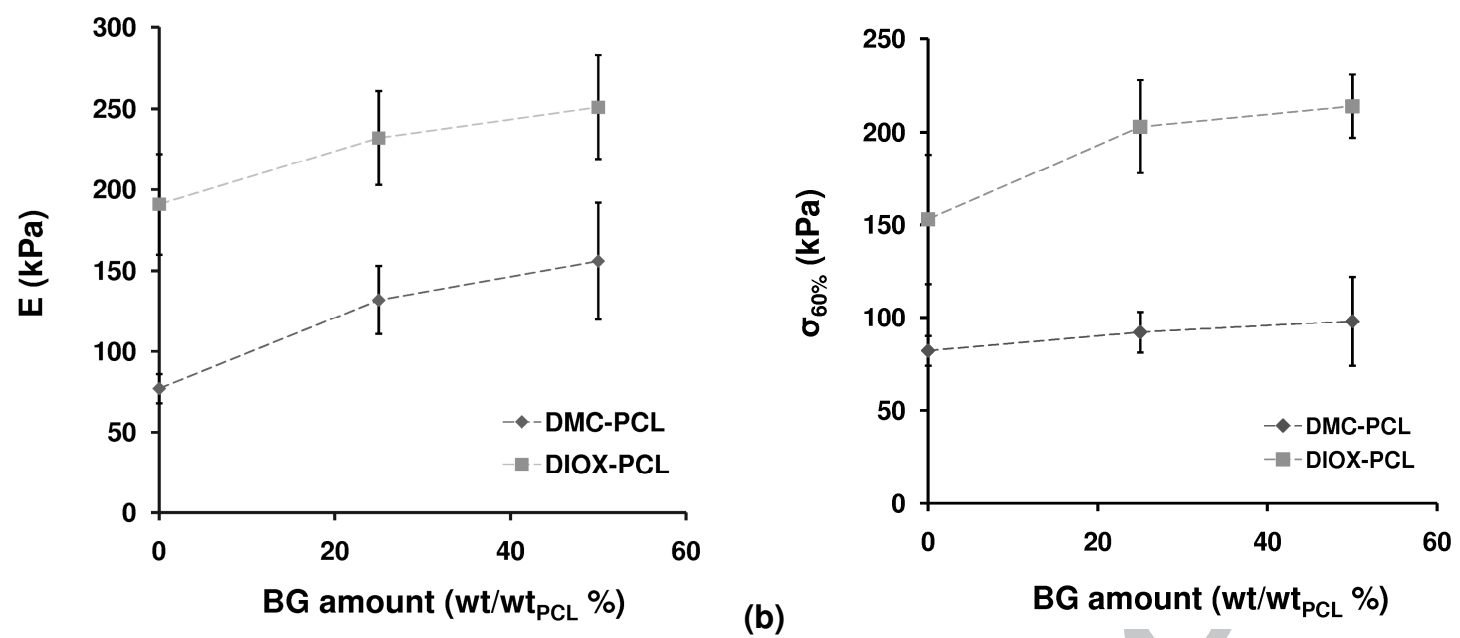

Figure 7. Elastic modulus (a) and compressive strength at deformation $60 \%, \sigma_{60 \%}$ (b) of PCL-BG composites at different BG content. 
Table 1. PCL-BG composites surface morphologies obtained by SLPS (SEM pictures 200x magnification, marker $50 \mu \mathrm{m})$. All samples contained $25 \mathrm{wt} \% \mathrm{BG}$.

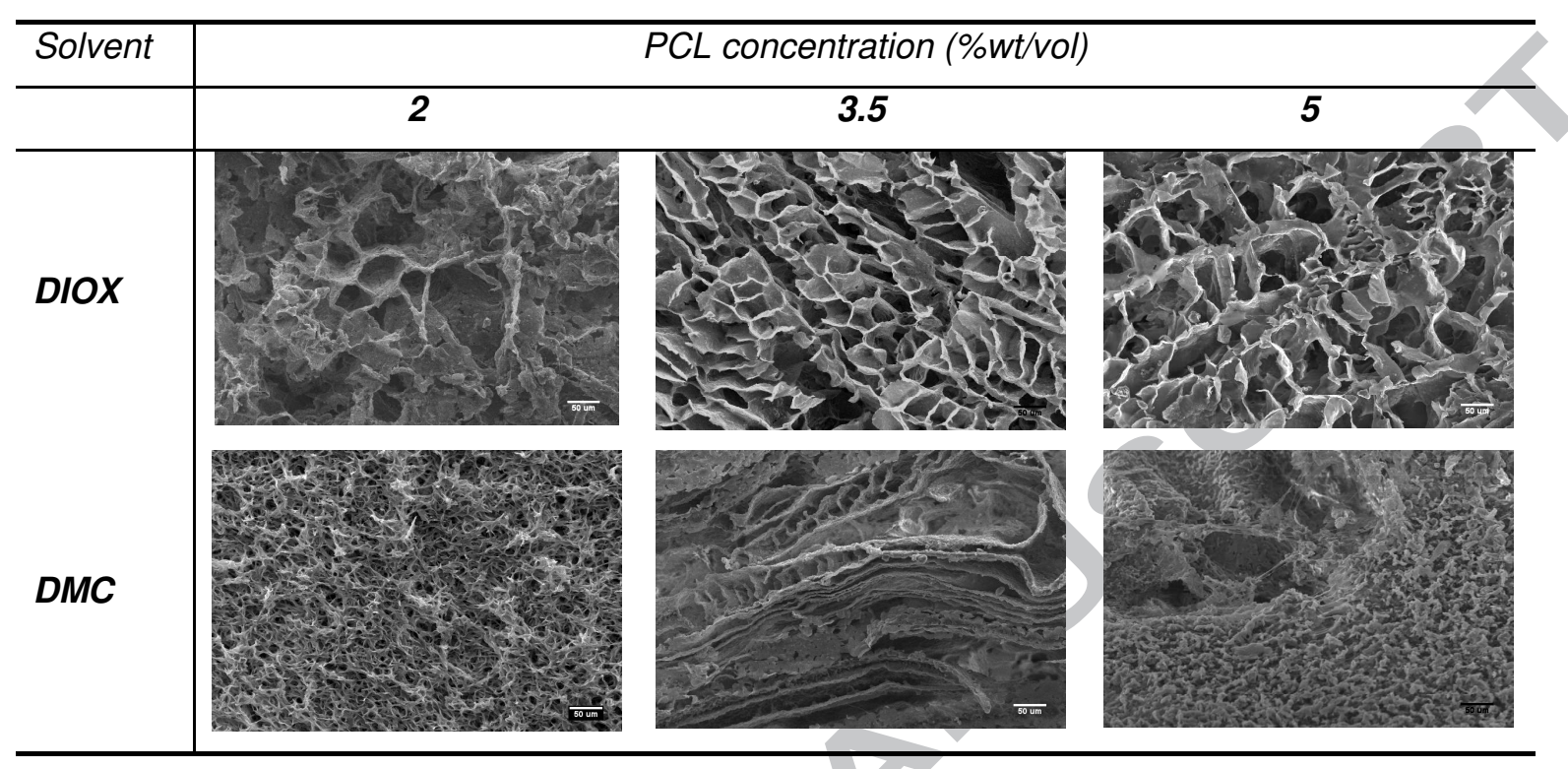


Table 2. PCL-BG composites cross-section morphologies obtained by SLPS (SEM pictures 50x magnification, marker $500 \mu \mathrm{m})$. All samples contained $25 \mathrm{wt} \% \mathrm{BG}$.

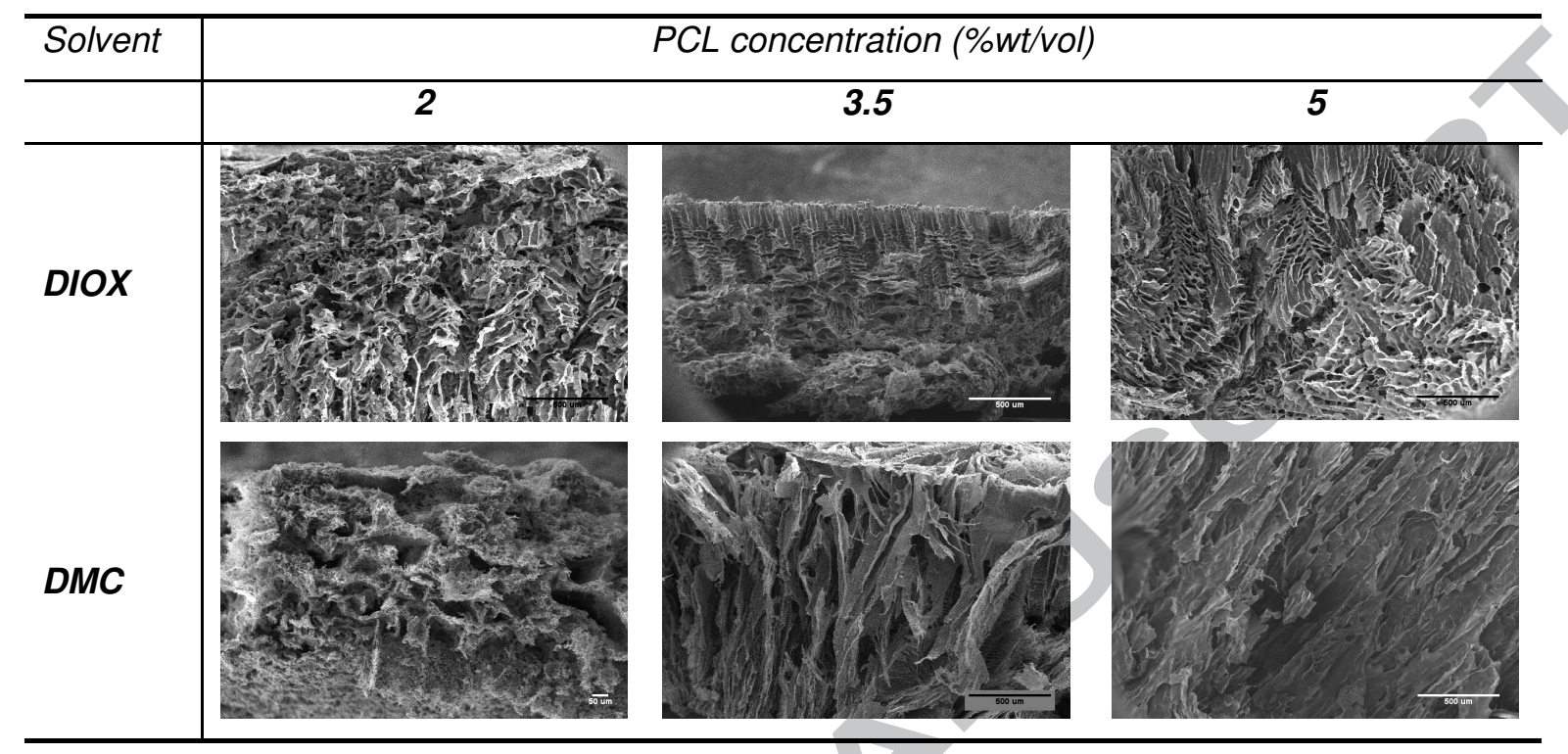


Table 3. Porosimetry results (instrument reliability: about 6\%).

\begin{tabular}{|c|c|c|c|c|c|c|}
\hline$\frac{\text { BG content }}{(\% \text { wt/wt }}$ & \multicolumn{2}{|c|}{$\underline{0}$} & \multicolumn{2}{|c|}{$\underline{25}$} & \multicolumn{2}{|c|}{$\underline{50}$} \\
\hline Solvent & DMC & DIOX & DMC & DIOX & DMC & DIOX \\
\hline Porosity & $\underline{89}$ & $\underline{88}$ & $\underline{91}$ & $\underline{89}$ & $\underline{92}$ & \\
\hline
\end{tabular}


Table 4. Results of compressive strength tests.

\begin{tabular}{|c|c|c|c|c|c|c|}
\hline & \multicolumn{2}{|c|}{$\underline{E}(\mathrm{kPa})$} & \multicolumn{2}{c|}{$\sigma_{30 \%}(\mathrm{kPa})$} & \multicolumn{2}{c|}{$\sigma_{60 \%}(\mathrm{kPa})$} \\
\hline $\begin{array}{c}\text { BG content } \\
\left(\mathbf{w t} / w t_{P C L} \%\right)\end{array}$ & $\underline{\mathrm{DMC}}$ & $\underline{\mathrm{DIOX}}$ & DMC & DIOX & DMC & DIOX \\
\hline $\mathbf{0}$ & $\underline{77 \pm 9}$ & $\underline{191 \pm 31}$ & $38 \pm 4$ & $76 \pm 15$ & $82 \pm 8$ & $153 \pm 35$ \\
\hline $\mathbf{2 5}$ & $\underline{132 \pm 21}$ & $\underline{232 \pm 29}$ & $40 \pm 5$ & $89 \pm 15$ & $92 \pm 11$ & $203 \pm 25$ \\
\hline 50 & $\underline{156 \pm 36}$ & $\underline{251 \pm 32}$ & $37 \pm 2$ & $99 \pm 13$ & $98 \pm 24$ & $214 \pm 17$ \\
\hline
\end{tabular}


Table 5. Observations on mineralization tests in SBF for PCL-BG composites and representative ESEM images (magnification: 500x; marker: $100 \mu \mathrm{m}$ ).

\begin{tabular}{|c|c|c|c|c|}
\hline BG content & \multicolumn{2}{|c|}{$25 \%\left(w t / w t_{P C L}\right)$} & \multicolumn{2}{|c|}{$50 \%\left(w t / w t_{P C L}\right)$} \\
\hline solvent & DMC & DIOX & DMC & DIOX \\
\hline \multicolumn{5}{|c|}{$\begin{array}{l}\text { immersion time } \\
1 \text { week }\end{array}$} \\
\hline & $\begin{array}{l}\text { Little apatite } \\
\text { precipitation, just } \\
\text { on } \mathrm{BG} \text { particles. } \\
\mathrm{NaCl} \text { and } \mathrm{CaCl}_{2} \\
\text { precipitates on the } \\
\text { whole surface. }\end{array}$ & $\begin{array}{l}\text { No apatite } \\
\text { precipitation. } \mathrm{NaCl} \\
\text { and } \mathrm{CaCl}_{2} \\
\text { precipitates on the } \\
\text { whole surface. }\end{array}$ & $\begin{array}{l}\text { BG particles on the } \\
\text { surface fully } \\
\text { covered by apatite } \\
\text { precipitates. } \mathrm{NaCl} \\
\text { present in high } \\
\text { amounts. }\end{array}$ & $\begin{array}{l}\text { Compact saline } \\
\text { crust on the whole } \\
\text { surface, mainly } \\
\text { composed by } \mathrm{NaCl} \\
\text { and } \mathrm{CaCl}_{2} \text { and } \\
\text { minor amounts of } \\
\text { apatite. }\end{array}$ \\
\hline \multicolumn{5}{|c|}{$\begin{array}{l}\text { immersion time } \\
2 \text { weeks }\end{array}$} \\
\hline & $\begin{array}{l}\text { Surface covered by } \\
\text { a large amount of } \\
\text { apatite. }\end{array}$ & $\begin{array}{l}\text { No apatite } \\
\text { precipitation. } \mathrm{NaCl} \\
\text { and } \mathrm{CaCl}_{2} \\
\text { precipitates on the } \\
\text { whole surface. }\end{array}$ & $\begin{array}{l}\text { Surface covered by } \\
\text { a large amount of } \\
\text { apatite. }\end{array}$ & $\begin{array}{l}\text { Surface covered by } \\
\text { a large amount of } \\
\text { apatite. No more } \\
\text { presence of } \mathrm{Na}^{+} \\
\text {and } \mathrm{Ca}^{2+} \text { salts. }\end{array}$ \\
\hline \multicolumn{5}{|c|}{$\begin{array}{l}\text { immersion time } \\
4 \text { weeks }\end{array}$} \\
\hline & $\begin{array}{l}\text { Little apatite } \\
\text { precipitation, just } \\
\text { on BG particles. }\end{array}$ & $\begin{array}{l}\text { No apatite } \\
\text { precipitation. } \mathrm{NaCl} \\
\text { and } \mathrm{CaCl}_{2} \\
\text { precipitates on the } \\
\text { whole surface. }\end{array}$ & $\begin{array}{l}\text { Surface covered by } \\
\text { a large amount of } \\
\text { apatite. }\end{array}$ & $\begin{array}{l}\text { Surface covered by } \\
\text { a large amount of } \\
\text { apatite. }\end{array}$ \\
\hline
\end{tabular}

